\title{
COVID, food, and the Parable of the Shmoo
}

\author{
M. Jahi Chappell, ${ }^{1,2}$
}

Accepted: 28 April 2020 / Published online: 12 May 2020

(c) Springer Nature B.V. 2020

\section{Introduction}

In the context of COVID-19, many things are uncertain. But there is little doubt that poorer people, and people in poorer countries, are more likely to die avoidable deaths-much as happens in "normal" times. But as COVID-19 has laid bare, avoidable deaths can proliferate even through the richest societies, if systems are not set up to use resources equitably.

Inequality, and its consequences, are not randomly distributed. Majority-black counties in the United States have COVID-19 infection and death rates respectively three and six times higher than majority-white counties. Women dominate many "essential" professions, particularly health care, social work, and retail. And undocumented workers continue to provide essential services (particularly in food and agriculture) in conditions and for pay that many US citizens refuse to tolerate. The usual precariousness for workers has been exacerbated, with limited systematic support in return.

Similar to the common observation in hunger studies, many challenges facing us with COVID-19 don't stem from absolute scarcity, but rather political and economic systems that have allocated scarcity to certain populations, even in the presence of plenty. Capitalists today would admonish Benjamin Franklin that you shouldn't sell one ounce of prevention when you can wait-and sell 16 ounce of cure!

This article is part of the Topical Collection: Agriculture, Food \& Covid-19.

M. Jahi Chappell

jahi@ foodfirst.org

1 Institute for Food \& Development Policy/Food First, Oakland, USA

2 Centre for Agroecology, Water \& Resilience, Coventry University, Coventry, UK

\section{The Parable of the Shmoo}

The contradictions between the interests of capitalists and people in general are a fundamental feature of our food and agriculture systems, with workers who are simultaneously called "essential" and "illegal"; hunger alongside dumping and waste; and a US healthcare system world-class in cost but middling in generating health. The outrage of the US's 40 million unnecessarily food insecure people is now joined by the US's tragically, preventably large shares of the world's COVID-19 cases, and deaths (respectively one third, and one quarter).

Sociologist Erik Olin Wright used the "Parable of the Shmoo" to explain why analyzing capitalism and class is vital to understanding contemporary problems like these. The mythical shmoos (originally seen in the comic strip L'il Abner) will endlessly and happily transform themselves into every basic material thing a human being needs, but cannot provide any luxury items (Wright 2000). Unsurprisingly, capitalists connive to destroy the shmoos. Wright explains why: for those whose increased prosperity depends on other people working for them for as little pay as possible, everyone getting their basic needs met for free is a tragedy-people might not work, or (worse yet) demand higher pay! For rational, self-interested capitalists, the best solution would obviously be for only capitalists to get shmoos. Second-best? Destroy them - the former status quo was good for capitalists! If forced to further choose, capitalists might concede that everyone getting shmoos is marginally better than the worst case (only workers getting them).

Things look different from the point of view of the rational, self-interested worker. For them, the first choice IS for everyone to get shmoos: all workers' basic needs are provided for, but at the same time, the fact that capitalists get them means that they have more resources and thus might (in theory) use them to pay workers more. For workers, the fact that shmoo-owning capitalists might pay workers more is the reason that destroying all the shmoos is actually workers' last choice. 
The Parable of the Shmoo elegantly illustrates why the beloved capitalist saying "a rising tide lifts all boats" says something different than they think: an actual rising tide lifts all boats only because additional water is distributed nearly perfectly evenly.

\section{What if we had a class war and everyone came?}

Under capitalism, it makes sense for access to food, healthcare, fair wages, COVID-19 tests and treatment, and more to remain scarce. But under systems set up to care for people, rather than capital, parity - paying farmers enough for farming to be profitable-would make sense (the median income from farming in the US is negative), as would paying other workers enough to afford fairly priced food. Similarly, healthcare for all would make everyone better off except for, perhaps, capitalists. But here's the thing about class war: capitalists "losing" would just mean fulfilling the promises of rising tides-sharing enough to lift everyone up. So let us unite! There may be nothing so effective as to unchain our shmoos.

\section{Reference}

Wright, E.O. 2000. Class counts. Cambridge: Cambridge University Press.

Publisher's Note Springer Nature remains neutral with regard to jurisdictional claims in published maps and institutional affiliations.

M. Jahi Chappell is a political agroecologist and the Executive Director of Food First / the Institute for Food \& Development Policy, and an Honorary Research Fellow at Coventry University's Centre for Agroecology, Water \& Resilience. He has authored numerous peer-reviewed articles, book chapters, and reports on agroecology, food sovereignty, and biodiversity conservation, as well as Beginning to End Hunger: Food and the Environment in Belo Horizonte, Brazil, and Beyond (UC Press, 2018). He has worked with and for social movements and communities across the United States and around the world. 